\title{
Dichorhavirus: a proposed new genus for Brevipalpus mite- transmitted, nuclear, bacilliform, bipartite, negative-strand RNA plant viruses
}

\author{
Ralf G. Dietzgen • Jens H. Kuhn - Anna N. Clawson • Juliana Freitas-Astúa • \\ Michael M. Goodin • Elliott W. Kitajima • Hideki Kondo • Thierry Wetzel • \\ Anna E. Whitfield
}

Received: 10 July 2013/ Accepted: 16 July 2013/Published online: 1 October 2013

(C) Springer-Verlag Wien 2013

\begin{abstract}
Orchid fleck virus (OFV) is an unassigned negative-sense, single-stranded (-)ssRNA plant virus that was previously suggested to be included in the family Rhabdoviridae, order Mononegavirales. Although OFV shares some biological characteristics, including nuclear cytopathological effects, gene order, and sequence similarities, with nucleorhabdoviruses, its taxonomic status is unclear because unlike all mononegaviruses, OFV has a segmented genome and its particles are not enveloped. This article analyses the available biological, physico-chemical, and nucleotide sequence evidence that seems to indicate that OFV and several other Brevipalpus mite-transmitted short bacilliform (-)ssRNA viruses are likely related and
\end{abstract}

R.G. Dietzgen and J. H. Kuhn are Members of the ICTV

Mononegavirales Study Group. R. G. Dietzgen, T. Wetzel, A. E. Whitfield are Members of the ICTV Rhabdoviridae Study Group.

The taxonomic changes suggested here have not been endorsed by the ICTV Executive Committee, may differ from any new taxonomy that is ultimately approved by the ICTV, and is presented for discussion only but has no official standing. The content of this publication does not necessarily reflect the views or policies of the US Department of Health and Human Services or of the institutions and companies affiliated with the authors. JHK performed this work as an employee of Tunnell Consulting, Inc., and ANC as the owner of Logos Consulting, Inc., both subcontractors to Battelle Memorial Institute under its prime contract with NIAID, under Contract No. HHSN272200700016I.

R. G. Dietzgen ( $\square)$

Queensland Alliance for Agriculture and Food Innovation, The

University of Queensland, St. Lucia, QLD 4072, Australia

e-mail: r.dietzgen@uq.edu.au

J. H. Kuhn · A. N. Clawson

Integrated Research Facility at Fort Detrick, National Institute of

Allergy and Infectious Diseases, National Institutes of Health,

Fort Detrick, Frederick, MD, USA may be classified taxonomically in novel species in a new free-floating genus Dichorhavirus.

\begin{tabular}{ll}
\multicolumn{2}{l}{ Abbreviations } \\
adj. & adjectivum (adjective) \\
fam. nov. & familia nova (new family) \\
fem. & femininum \\
gen. nov. & genus novum (new genus) \\
geo. & geographic \\
IPA & International Phonetic Alphabet \\
Lat. & Latin \\
n. & nomen substantivum (noun) \\
Neo-Lat. & Neo-Latin \\
neut. & neutrum \\
pl. & numerus pluralis (plural) \\
sg. & numerus singularis (singular) \\
sp. nov. & species nova (new species) \\
suff. & suffix
\end{tabular}

Introduction

There are more than 60 large bacilliform or bullet-shaped plant viruses that have not been characterized much beyond

\author{
J. Freitas-Astúa \\ Embrapa Cassava and Fruits, Cruz das Almas, BA, Brazil \\ M. M. Goodin \\ Plant Pathology, University of Kentucky, Lexington, KY, USA \\ E. W. Kitajima \\ NAP-MEPA, ESALQ/USP, Piracicaba, SP, Brazil
}


electron microscopic visualization of their virions in infected plant tissues [19]. Due to their characteristic virion shapes, which at least superficially resemble rhabdoviruses, they had been considered potential rhabdoviruses [19]. At least three of these 60 viruses, citrus leprosis virus (CiLV), coffee ringspot virus (CoRSV), and orchid fleck virus (OFV), are transmitted by false spider mites of the genus Brevipalpus Donnadieu, 1875 (Arthropoda: Arachnida: Acari: Trombidiformes: Tenuipalpidae). The 1st and 2nd Reports of the International Committee on Taxonomy of Viruses (ICTV) did not list any of these three viruses [15, 55]. The 3rd Report listed OFV as an ungrouped plant rhabdovirus [38]. In the 4th Report, CiLV, CoRSV, and OFV were recognized as ungrouped rhabdoviruses ("Citrus leprosis "rhabdovirus", "coffee ringsport "rhabdovirus", and "orchid fleck "rhabdovirus", , respectively) [39]. In the 5th Report, CiLV and OFV were considered "possible" members, and CoRSV a "probable" member, of the "plant rhabdovirus group" [17]. The 6th Report considered all three viruses "possible" members of the family Rhabdoviridae and listed them as "unassigned plant rhabdoviruses" [56]. In the 7th Report, CiLV and CoRSV remained listed as "unassigned plant rhabdoviruses" [53], but OFV was removed from the rhabdovirus section and classified as an "unassigned plant virus" [5]. This classification was upheld for all three viruses in the 8th Report [40, 49]. Further studies on citrus leprosis disease revealed that CiLV can be differentiated into two different viruses: the cytoplasmic type CiLV-C and the nuclear type CiLV-N [2]. In the latest, 9th ICTV Report, CiLV-C is listed as a member of the novel genus Cilevirus [37]; CiLV-N and CoRSV are no longer listed [21], and OFV is listed as an unclassified virus [1].

As a group, CiLV-N, CoRSV, and OFV produce virions that have similar particle morphology clearly different from bona fide rhabdovirions. In addition, the genomes of CiLV-N, CoRSV, and OFV are all composed of bipartite negative-sense, single-stranded (-)ssRNAs. This contradicts the current member classification criteria for the order Mononegavirales, which exclusively groups viruses with single-stranded monopartite negative-strand RNA genomes $[14,42,43]$. If the order demarcation criteria were modified to "have predominantly non-segmented genomes",

\author{
H. Kondo \\ Institute of Plant Science and Resources, Okayama University, \\ Kurashiki, Japan \\ T. Wetzel \\ RLP Agroscience, AlPlanta, Neustadt, Germany \\ A. E. Whitfield \\ Plant Pathology, Kansas State University, Manhattan, KS, USA
}

then these CiLV-N, CoRSV, and OFV viruses could be considered as possible order members. However, a second characteristic of mononegavirions is that they have lipid envelopes - a feature which CiLV-N, CoRSV, and OFV particles lack, although virions appear to at least associate with cellular membranes. Based on sequence similarities of nucleocapsid protein, putative glycoprotein (G) and RNAdependent RNA polymerase (L) genes with those of nucleorhabdoviruses (genus Nucleorhabdovirus), OFV has been suggested as a member of a new species to be included in a new rhabdoviral genus (Dichorhavirus) [29] or as a member of an unnamed free-floating genus outside of the order Mononegavirales [41]. This article proposes the taxonomic classification of $\mathrm{OFV}$ and similar plant viruses as members of novel species in the new freefloating genus Dichorhavirus, and considers options for future higher classification.

\section{Bacilliform 'nuclear-type' viruses transmitted by false spider mites}

Depending on their site of replication and accumulation in plant cells, Brevipalpus mite-transmitted viruses have been classified into nuclear (BrTV-N) and cytoplasmic (BrTVC) types [25]. CiLV-N, CoRSV, OFV, and another similar virus that has never been listed in ICTV Reports, Clerodendrum chlorotic spot virus (ClCSV), are considered nuclear types that potentially replicate in the nuclei of infected plant cells [6, 23, 24, 28, 44], in which they cause similar characteristic cytopathic effects (electron-lucent viroplasms) [22, 31]. Another virus not listed in ICTV Reports, Viola ringspot virus (ViRSV), is a virus with properties similar to those of CiLV-N, ClCSV, CoRSV, and OFV, but its vector is currently unknown [18].

Brevipalpus mites are capable of feeding on diverse tissues of host plants, including leaves, flowers, fruits, and branches. Feeding of these mites causes direct damage to plants and may induce symptoms such as chlorosis, necrosis, gall formation, and malformation of fruit [9]. Mites belonging to at least three distinct species can persistently transmit bacilliform 'nuclear-type' viruses, including B. californicus Banks, 1904; B. phoenicis Geijskes, 1939; and B. obovatus Donnadieu, 1875 (reviewed in ref. [10]). A minimum inoculation access period of $30 \mathrm{~min}$ is required for transmission of $\mathrm{OFV}$ by $B$. californicus mites, and mites are capable of transmitting OFV after a three-week latent period on a virus-resistant host [28]. OFV was transmitted after mites had molted, which suggests that the virus circulates throughout the body of the mite, providing additional evidence for persistent transmission [28]. Brevipalpus-transmitted bacilliform 'nuclear-type' viruses are not transovarially transmitted [34]. Two lines of initial 
evidence currently suggest that CoRSV, CiLV-N, and $\mathrm{ClCSV}$ replicate in their mite vectors: transmission electron microscopy shows the presence of viroplasms in viruliferous mites and RT-qPCR shows increased virus titers ([24, 25]; Kitajima, Bastianel, Freitas-Astúa, unpublished data).

\section{Citrus leprosis virus, nuclear type (CiLV-N)}

Recently, CiLV-N has been identified as the likely cause of a mild form of citrus leprosis disease in Florida, USA [27]. CiLV-N produces bacilliform or rod-shaped particles (40$50 \times 100-110 \mathrm{~nm}$ ) that can be found in the nucleus and cytoplasm and are often associated with membranes (Table 1). The nucleus of infected cells features an electron-lucent viroplasm. The complete bipartite genome of a Mexican isolate of CiLV-N has recently been sequenced [45]. The CiLV-N genome, composed of RNA $1(\approx 6.4 \mathrm{~kb})$ and RNA $2(\approx 6.0 \mathrm{~kb})$ closely resembles that of OFV, with 92-95\% sequence similarity at the nucleotide level and 96$98 \%$ at the amino acid level. This suggests that this Mexican isolate of CiLV-N may be considered a citrusinfecting strain of OFV rather than a distinct virus [45]. Sequencing of other isolates from different countries (there are known isolates in Panamá and Brazil) and from various citrus species will help to determine whether or not the name CiLV-N should be abandoned.

\section{Clerodendrum chlorotic spot virus (CICSV)}

Chlorotic spots on the ornamental plant Clerodendrum $x$ speciosum Dombrain (Lamiales: Lamiaceae) linked to Brevipalpus mite infestations were observed in Brazil in 2000 [24]. Electron-microscopic analysis of thin sections revealed electron-translucent viroplasms in the nuclei of infected leaf cells. Short bullet-shaped virions $(40 \times 100$ $110 \mathrm{~nm}$ ) were observed in the nuclei and cytoplasm. ClCSV was transmitted by $B$. phoenicis mites feeding on symptomatic and then healthy $C$. $x$ speciosum plants and plants of several other species, causing chlorotic spots on inoculated leaves (Table 1) [24]. The virus was also mechanically transmissible in leaf extracts to several indicator plants. ClCSV was purified, and a rabbit polyclonal antiserum was prepared that reacted strongly with ClCSV in ELISA. Antisera against OFV and CoRSV reacted weakly with purified ClCSV, indicating some shared antigenic sites [24]. RT-PCR was used to amplify a 311-bp fragment of the putative polymerase gene of $\mathrm{ClCSV}$, and another primer set was used to detect the virus in infected mites [34]. A BLAST P search showed that the deduced amino acid sequence of this $\mathrm{L}$ gene fragment (HQ853700) was $68 \%$ identical to the corresponding fragment of the $\mathrm{L}$ protein of $\mathrm{OFV}$, with an $\mathrm{E}$ value of $3 \mathrm{e}^{-40}$ and $48 \%$ or less sequence identity to the $\mathrm{L}$ proteins of nucleorhabdoviruses.

\section{Coffee ringspot virus (CoRSV)}

Coffee ringspot was first described in Brazil in 1938 and has been generally considered as a minor disease of low economic importance, except for several disease epidemics in Brazil in the 1990s [3]. CoRSV produces short bacilliform particles $(45 \times 100-140 \mathrm{~nm})$ that are transmitted by Brevipalpus phoenicis mites (Table 1). Virions can be found in the nucleus and cytoplasm of infected cells, often associated with membranes [6]. Characteristic electron translucent nuclear inclusions are indicative of virus replication in the nucleus. The complete genome sequence of CoRSV is not currently available, but as for OFV, agarose gel electrophoresis of RNA extracted from purified CoRSV preparations (using an OFV purification protocol) yielded two bands of $\approx 6,000$ and $\approx 6,400$ nucleotides, respectively [4]. The partial deduced amino acid sequence of the $\mathrm{L}$ protein from a Brazilian isolate of CoRSV showed high similarity across 305 amino acids with OFV L protein $\left(61 \%\right.$ identity, E-value $3 \mathrm{e}^{-124}$ ) and 30-35\% identity with that of nucleorhabdoviruses (Locali-Fabris, Freitas-Astúa and Machado, upublished data). A short fragment of that $\mathrm{L}$ gene has been deposited in GenBank (Table 1; [27]). A BLAST $N$ search against this sequence revealed the $\mathrm{L}$ gene sequences on RNA 2 of both sequenced OFV isolates as the closest match, with $71 \%$ nucleotide sequence identity across $77 \%$ of the 394-nt CoRSV sequence and an E-value of $1 \mathrm{e}^{-32}$. This sequence was used to design a pair of CoRSV-specific primers used for virus detection by RTPCR in plants of several Coffea species [26]. The apparent nucleotide sequence similarity between CoRSV and OFV was also supported by unpublished RT-PCR results, showing that the $\mathrm{N}$ gene of CoRSV could be weakly amplified using primers designed from the OFV $\mathrm{N}$ gene sequence (cited in ref. [22]). However, tissues infected with CoRSV did not react strongly with OFV antiserum in indirect ELISA or immunocytochemical assays [4, 22], nor did tissues infected with OFV give clear positive reactions with CoRSV antiserum in indirect ELISA [4]. Nevertheless, there were slight, yet consistently higher ELISA readings in heterologous reactions of infected samples compared to those in healthy controls. Similarly, only slight labelling of tissue sections was seen by in situ immunogold experiments in heterologous reactions using anti-CoRSV and anti-OFV sera, while the homologous reactions were strong [4]. Altogether, these data indicate a 


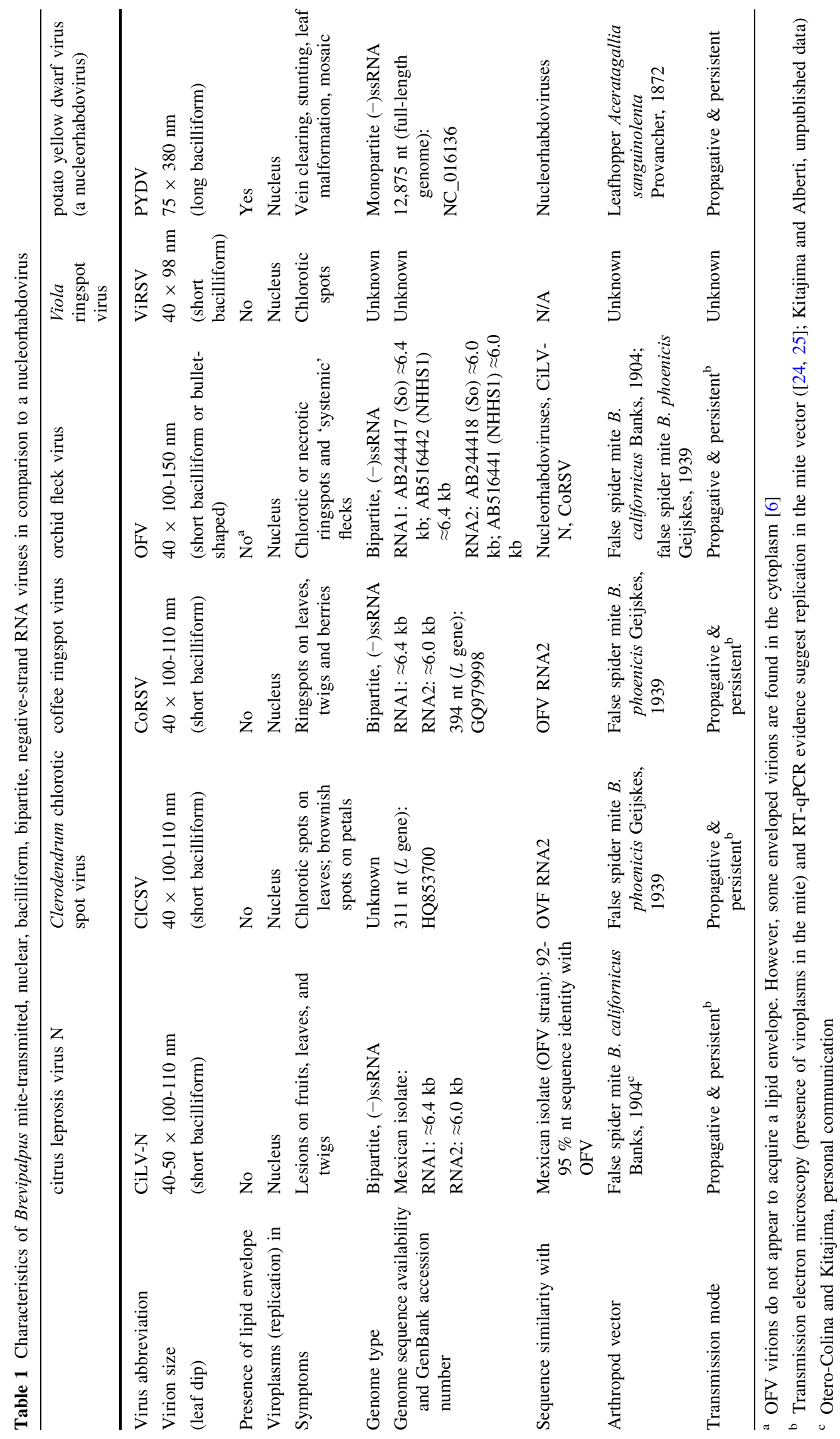


clear but distant relationship between CoRSV and OFV [4, 22].

\section{Orchid fleck virus (OFV)}

The history, etiology, serology, epidemiology, molecular biology, and detection of OFV and the pathology and prevention methods of orchid fleck disease were recently reviewed in detail [41]. Briefly, OFV was discovered in Japan in 1969 [12]. It is an important viral pathogen of orchids because it causes chlorotic or necrotic spots in orchids of many species and has a global distribution [22]. The particles of OFV superficially resemble those of plant rhabdoviruses, but they are significantly smaller $(40 \times 100$ $150 \mathrm{~nm}$ ) and have no clearly distinguishable lipid envelope [7, 22, 28] (Table 1). Outer lipid membranes were not observed in purified OFV particles, but in rare cases, enveloped virions were seen in infected plant cells [4]. In thin sections of infected plant tissue, some virions were arranged radially, surrounded by a membrane. This so-called "spoke wheels" configuration is a typical feature of OFV and the other viruses discussed here. Unlike mononegaviruses, all of which produce enveloped particles, purified orchid fleck virions remain structurally intact and infectious after treatment with non-ionic detergents such as Triton X-100 under high-salt conditions [13, 30]. Cytopathic effects caused by OFV resemble those of nucleorhabdoviruses by developing an electron-lucent inclusion (viroplasm) in the nuclei of infected cells [31].

The (-)ssRNA genome of OFV isolates So and NHHS1 consists of two molecules, RNA 1 (6,413 nt) and RNA 2 $(6,001 \mathrm{nt})$, with a total coding capacity of $\approx 12.4 \mathrm{~kb}[20$, 29]. The genome sequences of both sequenced isolates (Table 1) are more than $98.5 \%$ identical [20]. RNA 1 encodes, in the complementary sense, five proteins representing the nucleocapsid protein $(\mathrm{ORF} 1 / \mathrm{N})$, putative phosphoprotein (ORF2/P), putative movement protein $(\mathrm{ORF} 3 / 3)$, putative matrix protein $(\mathrm{ORF} / \mathrm{M})$, and putative glycoprotein (ORF5/G). RNA 2 encodes an RNA-dependent RNA polymerase (ORF6/L). Therefore, despite having a divided genome, the gene order of OFV resembles that of plant rhabdoviruses, all of which have a monopartite genome of 11-13 kb and the general gene order 3'-N-P-3M-G-L-5' (Fig. 1; Table 2) [11]. The $\mathrm{N}$ and L, and to a lesser degree $\mathrm{G}$, proteins of $\mathrm{OFV}$ have low but clear sequence similarity to cognate proteins of nucleorhabdoviruses, whereas the other gene products have no significant similarities to other known proteins [20, 29] (Table 3). Phylogenetic analysis of the $\mathrm{L}$ protein core module suggests that OFV is most closely related to nucleorhabdoviruses (Fig. 2). As far as this has been investigated, similarities between OFV and rhabdoviruses also extend to the 3'- and 5'-terminal complementary sequences of the genomic RNA and the conserved intergenic sequences [29].

Two groups of OFV isolates could be distinguished from sequence analysis of a 660-bp RT-PCR-amplified fragment of the $\mathrm{N}$ gene. Sequences between groups differed by at least $15.6 \%$ and $1.8 \%$ at the nucleotide and amino acid level, respectively, whereas within-group nucleotide sequence differences were less than $2 \%$ [3]. A recent study of a 328-bp N gene fragment from OFV isolates collected in Brazil, Costa Rica and Australia confirmed the two groups and showed similar sequence diversity between and within the groups [33]. OFV N gene fragment sequences of isolates from Japan, Germany, Korea and China are closely related to each other and distantly related to $\mathrm{N}$ gene regions of plant rhabdoviruses, with nucleorhabdoviruses being the closest relatives $[3,20$, 29]. In SDS-PAGE and western blot analyses of purified particles, the structural proteins $\mathrm{N}, \mathrm{P}$, and $\mathrm{M}$, and also small amounts of $\mathrm{L}$ protein, were detected, but not the $\mathrm{G}$ protein

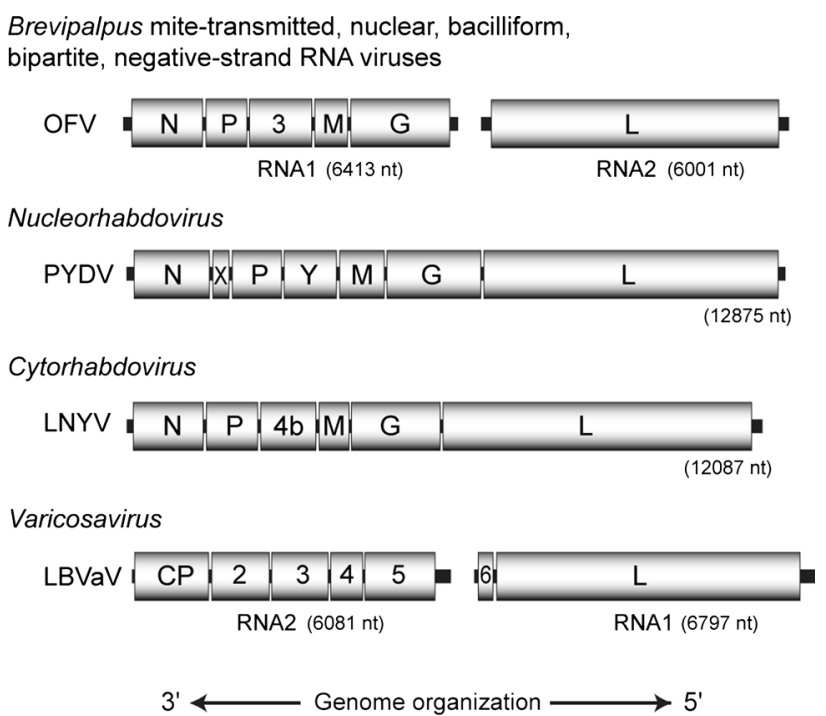

Fig. 1 Comparative genome organization of OFV-So and representative members of the genera of plant-infecting viruses (Nucleorhabdovirus and Cytorhabdovirus) of the family Rhabdoviridae and the unassigned genus Varicosavirus. OFV RNA1 encodes 49 $\mathrm{kDa}$ (ORF1: nucleocapsid protein N), $26 \mathrm{kDa}$ (ORF2: putative phosphoprotein $\mathrm{P}$ ), $38 \mathrm{kDa}$ (ORF3: putative movement protein), 20 kDa (ORF4: putative matrix protein M) and $61 \mathrm{kDa}$ (ORF5: putative glycoprotein $\mathrm{G}$ ) proteins, and RNA2 encodes a single protein of 212 kDa (ORF6: large polymerase protein L) [29, 30]. Virus names and GenBank/Refseq accession numbers are as follows: Brevipalpus mitetransmitted, nuclear, bacilliform, bipartite, negative-strand RNA viruses - orchid fleck virus (OFV; RNA1: NC_009608, RNA2: NC_009609), nucleorhabdovirus - potato yellow dwarf virus (PYDV; NC_016136), cytorhabdovirus - lettuce necrotic yellows virus (LNYV; NC_007642), varicosavirus - lettuce big-vein associated virus (LBVaV: NC_011558, RNA2: NC_011568). The genomic locations in the 3'-5' negative-sense arrangement are shown, as well as the relative sizes of the viral genes. The gene junction sequences for OFV are not yet clearly defined 
Table 2 Comparison of genome size and encoded proteins of plant (-)ssRNA viruses

\begin{tabular}{|c|c|c|c|c|c|c|c|c|c|}
\hline \multirow[t]{2}{*}{ Genus } & \multirow[t]{2}{*}{ Virus name (abbreviation) } & \multirow[t]{2}{*}{$\begin{array}{l}\text { Genome } \\
\text { Size (nt) }\end{array}$} & \multicolumn{7}{|c|}{$\begin{array}{l}\text { Proteins (kDa) } \\
\text { ORF \# } \\
\text { (putative function/denomination) }\end{array}$} \\
\hline & & & $1(\mathrm{~N} / \mathrm{CP})$ & $\mathrm{X}^{*}$ & $2(\mathrm{P})$ & $3(\mathrm{MP})$ & $4(\mathrm{M})$ & $5(\mathrm{G})$ & $6(\mathrm{~L})$ \\
\hline Nucleorhabdovirus & $\begin{array}{l}\text { potato yellow dwarf virus } \\
\text { (PYDV) }\end{array}$ & $\begin{array}{l}\text { Nonsegmented } \\
12,875\end{array}$ & 52 & 9.7 & 31 & 33 & 29 & 70 & 220 \\
\hline $\begin{array}{l}\text { Brevipalpus mite-transmitted, nuclear, } \\
\text { bacilliform, bipartite, negative-strand } \\
\text { RNA viruses }\end{array}$ & orchid fleck virus (OFV) & $\begin{array}{l}\text { RNA 1: } 6413 \\
\text { RNA 2: } 6001\end{array}$ & 49 & - & 26 & 38 & 20 & 61 & 212 \\
\hline Varicosavirus & $\begin{array}{l}\text { lettuce big vein-associated } \\
\text { virus (LBVaV) }\end{array}$ & $\begin{array}{l}\text { RNA 1: } 6797 \\
\text { RNA 2: } 6081\end{array}$ & 44 & - & 36 & 32 & 19 & 41 & 232 \\
\hline
\end{tabular}

* A protein of unknown function and N/CP indicates the different naming of ORF \#1 in the listed genera

Table 3 Amino acid sequence similarity (\%) comparison between OFV-So and plant rhabdoviruses

\begin{tabular}{|c|c|c|c|c|c|}
\hline Genus & Virus name (accession number) & Virus abbreviation & $\mathrm{N}$ protein & G protein & $\mathrm{L}$ protein \\
\hline \multirow[t]{2}{*}{ Cytorhabdovirus } & lettuce necrotic yellows virus (AJ867584) & LNYV & $24\left(2 \mathrm{e}^{-8}\right)^{\mathrm{a}}$ & $23(7.7)$ & $31\left(3 \mathrm{e}^{-155}\right)$ \\
\hline & northern cereal mosaic virus (AB030277) & NCMV & $\mathrm{ND}^{\mathrm{b}}$ & $\mathrm{ND}^{\mathrm{b}}$ & $29\left(2 \mathrm{e}^{-120}\right)$ \\
\hline \multirow[t]{7}{*}{ Nucleorhabdovirus } & maize fine streak virus (AY618417) & MFSV & $27\left(8 \mathrm{e}^{-25}\right)$ & $\mathrm{ND}^{\mathrm{b}}$ & $38(0.0)$ \\
\hline & maize mosaic virus (AY618418) & MMV & $27\left(1 \mathrm{e}^{-23}\right)$ & $\left.218 \mathrm{e}^{-6}\right)$ & $38(0.0)$ \\
\hline & potato yellow dwarf virus (GU734660) & PYDV & $27\left(3 \mathrm{e}^{-23}\right)$ & $23\left(5 \mathrm{e}^{-9}\right)$ & $38(0.0)$ \\
\hline & rice yellow stunt virus (AB011257) & RYSV & $27\left(9 \mathrm{e}^{-25}\right)$ & $25\left(7 \mathrm{e}^{-16}\right)$ & $36(0.0)$ \\
\hline & sonchus yellow net virus (L32603) & SYNV & $24\left(5 \mathrm{e}^{-17}\right)$ & $21(3.3)$ & $34(0.0)$ \\
\hline & maize Iranian mosaic virus (DQ186554) & MIMV & $27\left(3 \mathrm{e}^{-21}\right)$ & $25(0.003)$ & $35(0.0)$ \\
\hline & taro vein chlorosis virus (AY674964) & TaVCV & $29\left(5 \mathrm{e}^{-27}\right)$ & $21\left(1 \mathrm{e}^{-4}\right)$ & $34(0.0)$ \\
\hline
\end{tabular}

a $\%$ identity (E-value); BLAST N searches were limited to virus (taxid 10239) entries

${ }^{b}$ Not detectable

[30]. Unlike the transmembrane glycoprotein spikes of enveloped rhabdovirions, the OFV G protein may exist in a soluble form with an unknown function, similar to the secreted glycoproteins of filoviruses [46, 52], although this has not been shown experimentally.

\section{Viola ringspot virus (ViRSV)}

Common violets (Viola odorata L.) with chlorotic spots and containing "small rhabdovirus-like particles" were first identified in 1981 in Australia [18], and the associated virus was named Viola ringspot virus (ViRSV). ViRSV produces bacilliform particles resembling those of OFV [18]. Virions are found in the nucleus and cytoplasm of infected cells in close association with cellular membranes. As with OFV and CoRSV infections, characteristic electron-lucent nuclear inclusions are indicative of ViRSV replication in the nucleus [18]. Its genome sequence and organization are unknown. However, the $\mathrm{N}$ gene of ViRSV was amplified by RT-PCR using primers designed from the OFV N gene sequence (cited in ref. [22]), indicating that these viruses may be related. Due to the limited data, it would be premature to suggest a taxonomic classification for this virus.

\section{Other plant viruses with segmented (-)ssRNA genomes and sequence similarities to rhabdoviruses}

Lettuce big-vein associated virus (LBVaV), the type member of the free-floating genus Varicosavirus, produces non-enveloped, rod-shaped particles of $18 \times 320-360 \mathrm{~nm}$ and is transmitted by the soil-borne fungus Olpidium brassicae Dang, 1886 [47, 54]. It differs considerably in virion morphology and vector from those of Brevipalpus mite-transmitted, nuclear, bacilliform, bipartite, (-)ssRNA viruses. The LBVaV bipartite (-)ssRNA genome is composed of two segments of $6.8 \mathrm{~kb}$ and $6.1 \mathrm{~kb}$ in length, respectively. Similar to rhabdoviruses, its genome has conserved intergenic regions and genes that are transcribed 


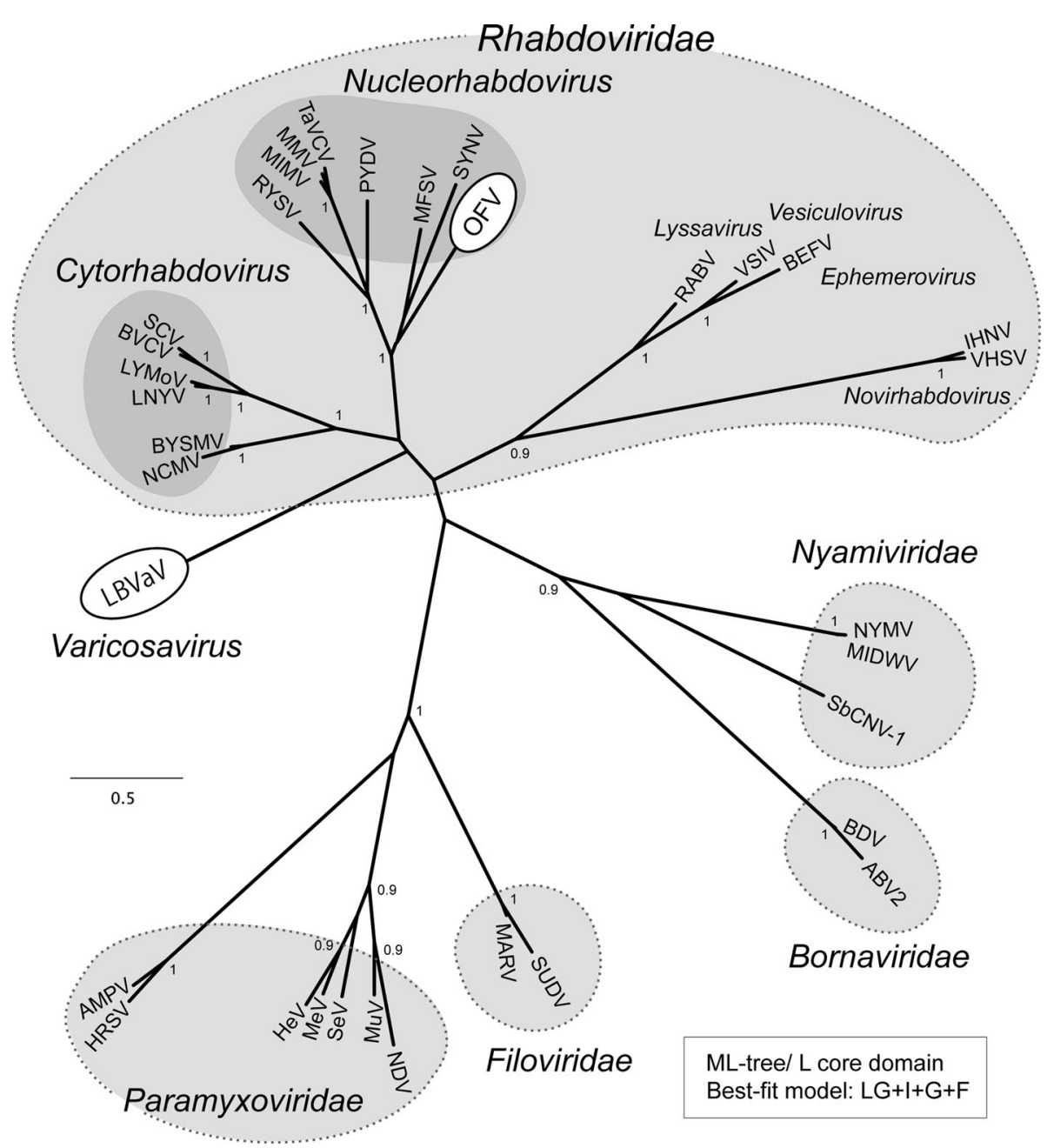

Fig. 2 Phylogenetic relationship of OFV to mononegaviruses and varicosaviruses. A maximum-likelihood tree was constructed using PhyML 3.0 (http://www.atgc-montpellier.fr/phyml/) based on a multiple amino acid sequence alignment of the RdRp (L) polymerase core module as described previously [32]. The best-fit model LG+I $+\mathrm{G}+\mathrm{F}$ was selected using ProtTest ver. 2.4 (http://darwin.uvigo.es/ software/prottest2_server.html). Virus names and GenBank/Refseq accession numbers are as follows: bornaviruses - Borna disease virus (BDV; NP_042024), avian bornavirus genotype 2 (ABV2; ADU05398); filoviruses - Sudan virus (SUDV; YP_138527), Marburg virus (MARV; YP_001531159); paramyxoviruses - Newcastle disease virus (NDV; NP_071471), Hendra virus (HeV; NP_047113), measles virus (MeV; NP_056924), Sendai virus (SeV; NP_056879), mumps virus (MuV; NP_054714), avian metapneumovirus (AMPV; YP_443845), human respiratory syncytial virus (HRSV; NP_056866); nyamiviruses (newly proposed family [36]) - Nyamanini virus (NYMV; YP_002905337), Midway virus (MIDWV; YP_002905331), soybean cyst nematode virus 1 (SbCNV-1; AEF56729). rhabdoviruses: lyssavirus - rabies virus (RABV; NP_056797), ephemerovirus - bovine ephemeral fever virus (BEFV; NP_065409), vesiculovirus - vesicular stomatitis Indiana virus

as monocistronic mRNAs (Table 2; Fig. 1) [51]. As is the case for other $(-)$ ssRNA viruses, the amino acid sequence of the conserved $\mathrm{L}$ protein polymerase motif of $\mathrm{LBVaV}$ has
(VSIV; NP_041716), novirhabdoviruses - infectious hematopoietic necrosis virus (IHNV; NP_042681), viral hemorrhagic septicemia virus (VHSV; NP_049550); cytorhabdovirus - LNYV (YP_425092), lettuce yellow mottle virus (LYMoV; YP_002308376), northern cereal mosaic virus (NCMV, NP_597914), strawberry crinkle virus (SCV; AAP03645), barley yellow striate mosaic virus (BYSMV; ACT21686); nucleorhabdovirus - PYDV (YP_004927971), maize fine streak virus (PYDV; YP_052849), maize mosaic virus (MMV; YP_052855), rice yellow stunt virus (RYSV; NP_620502), sonchus yellow net virus (SYNV; NP_042286), taro vein chlorosis virus (TVCV; YP_224083), maize Iranian mosaic virus (MIMV; YP_002308459); unclassified plant rhabdovirus - raspberry vein chlorosis virus (RVCV; CBL76312); varicosavirus - LBVaV (YP_002308576), Brevipalpus mite-transmitted, nuclear, bacilliform, bipartite, negative-strand RNA viruses - OFV (YP_001294929). Dashed circles: the members of the Mononegavirales; solid circles: Brevipalpus mite-transmitted, nuclear, bacilliform, bipartite, negativestrand RNA viruses and members of the genus Varicosavirus. Numbers at the nodes represent aLRT values derived using an $\mathrm{SH}$ like calculation (only values greater than 0.9 are shown)

significant similarities to other L proteins, especially those of plant rhabdoviruses, but is more distantly related to that of OFV (Fig. 2) [29, 47]. 
Table 4 Proposed new taxonomy for Brevipalpus mite-transmitted, nuclear, bacilliform, bipartite, negative-strand RNA viruses

\begin{tabular}{lll}
\hline Proposed genus & Proposed species & Member virus (abbreviation) \\
\hline Dichorhavirus & & \\
& Clerodendrum chlorotic spot dichorhavirus & Clerodendrum chlorotic spot virus (ClCSV) \\
& Coffee ringspot dichorhavirus & coffee ringspot virus (CoRSV) \\
& Orchid fleck dichorhavirus & orchid fleck virus (OFV) \\
\hline
\end{tabular}

Proposed type species is underlined

Taxonomic placement of Brevipalpus mite-transmitted, nuclear, bacilliform, bipartite, negative-strand RNA viruses

OFV is currently the only completely sequenced short bacilliform bipartite (-)ssRNA virus with significant nucleocapsid protein and polymerase sequence similarities to nucleorhabdoviruses in the family Rhabdoviridae, order Mononegavirales. Several other putative plant (-)ssRNA viruses share biological, physico-chemical, and sequence similarities with OFV. It therefore seems reasonable to create a new free-floating genus, tentatively named Dichorhavirus (roughly meaning rhabdo-like viruses whose genomes are split in two), containing Orchidfleck dichorhavirus as the type species and two other species, Coffee ringspot dichorhavirus and Clerodendrum chlorotic spot dichorhavirus (Table 4) [50]. Because the only sequenced isolate of CiLV-N appears to be a strain of OFV, we do not propose the inclusion of CiLV-N in a new species at this stage. Until more detailed information becomes available for ViRSV, it should be considered as a possible member of the new genus.

\section{Template descriptions of taxa and viruses}

Description of Dichorhavirus gen. nov. Dietzgen et al. 2013 (tentative)

Etymology of Dichorhavirus: sigil of dich(o)-, from Greek $\delta \iota \chi \alpha$ - meaning "in two, apart or asunder"; rhabdovirus; and -virus - ending denoting a virus genus $\rightarrow$ Neo-Lat. n. neut. sg. Dichorhavirus - the genus of rhabdo-like viruses that are split in two.

- Valid taxon name (fulfills ICVCN Article 3 Rule II3.8): yes, because name is compliant with ICVCN Article 3 Rules, in particular Rules IV-3.26, IV-3.27, IV-3.28, and IX-3.39 [19]; because it has been published [this article]; and because it is associated with descriptive material

- Accepted name (fulfills ICVCN Article 3 Rule II-3.8): no, because this name has yet to go through the ICTV approval process

- Use of the taxon:

- Style: capitalized, italicized, zero article
- Suggested pronunciation: [dar kprə'vairəs] (IPA); dahy-ko-ruh-vahy-ruhs (English phonetic notation)

- Abbreviation: none

- Use of taxon vernaculars:

- n. sg.: dichorhavirus (-virus: ending denoting a physical member of a virus genus [19]). Suggested pronunciation: [daI, kprə'vaIrəs] (IPA); dahy-ko-ruhvahy-ruhs (English phonetic notation)

- n. pl. dichorhaviruses. Suggested pronunciation: [dai kprə'varrəsiz] (IPA); dahy-ko-ruh-vahy-ruhs-iz (English phonetic notation)

- adj.: dichorhavirus/dichorhaviral. Suggested pronunciation: [daI,kprə'vaIrəs]/[daI,kprə'vairəl] (IPA); dahy-ko-ruh-vahy-ruhs/dahy-ko-ruh-vahy-ruhl (English phonetic notation)

- Style: lower case, not italicized, one word, zero article

- Abbreviation: none

- Type species: Orchid fleck dichorhavirus (tentative, see below)

- Genus members: species Clerodendrum chlorotic spot dichorhavirus (tentative, see below), Coffee ringspot dichorhavirus (tentative, see below), Orchid fleck dichorhavirus (tentative, see below)

Description of Clerodendrum chlorotic spot dichorhavirus sp. nov. Dietzgen et al. 2013 (tentative)

Etymology of Clerodendrum chlorotic spot dichorhavirus: derived from Clerodendrum chlorotic spot disease (the disease caused by members of this species); and Dichorhavirus the genus of dichorhaviruses $\rightarrow$ the clerodendrum chlorotic spot-causing species of dichorhaviruses.

- Valid taxon name (fulfills ICVCN Article 3 Rule II3.8): yes, because name is compliant with ICVCN Article 3 Rules, in particular Rule IX-3.40 [19]; because it has been published [this article]; and because it is associated with descriptive material

- Accepted name (fulfills ICVCN Article 3 Rule II-3.8): no, because this name has yet to go through the ICTV approval process 
- Use of the taxon:

- Style: capitalized, italicized, zero article

- Suggested pronunciation: [,klerə'dendrəm klo'rotrk sppt daI,kprə'varrəs ${ }^{1}$ ], (IPA); kler-uh-den-druhm klaw-rot-ik spot dahy-ko-ruh-vahy-ruhs (English phonetic notation)

- Abbreviation: none

- Use of taxon vernaculars:

- n. sg.: Clerodendrum chlorotic spot dichorhavirus. Suggested pronunciation: [klerə'dendrəm klə'rotrk sppt daI kprə'vairəs], (IPA); kler-uh-den-druhm klaw-rot-ik spot dahy-ko-ruh-vahy-ruhs (English phonetic notation)

- n. pl. Clerodendrum chlorotic spot dichorhaviruses. Suggested pronunciation: [klerə'dendrəm klo'rotrk sppt dar,kprə'varrəsiz], (IPA); kler-uh-den-druhm klaw-rot-ik spot dahy-ko-ruh-vahy-ruhs-iz (English phonetic notation)

- adj.: Clerodendrum chlorotic spot dichorhavirus/ Clerodendrum chlorotic spot dichorhaviral. Suggested pronunciation: [, klerə'dendrəm klo'rotık sppt dai,kprə'vaIrəs]/[,klerə'dendrəm klo'rotık sppt daI ,kprə'varrəl] (IPA); kler-uh-den-druhm klaw-rot-ik spot dahy-ko-ruh-vahy-ruhs/kler-uh-den-druhm klaw-rot-ik spot dahy-ko-ruh-vahy-ruhl (English phonetic notation)

- Style: lower case, not italicized, one word, zero article

- Abbreviation: none

- Species members are characterized by having the properties of dichorhaviruses; having an L gene polymerase motif nucleotide sequence different from the type virus of the type species of the genus Dichorhavirus (orchid fleck virus) by $>25 \%$; and infecting Clerodendrum spp.

- Suggested type virus: Clerodendrum chlorotic spot virus (ClCSV)

- Species members: Clerodendrum chlorotic spot virus (ClCSV)

Description of Coffee ringspot dichorhavirus sp. nov.

Dietzgen et al. 2013 (tentative)

Etymology of Coffee ringspot dichorhavirus: derived from coffee ringspot disease (the disease caused by members of this species); and Dichorhavirus - the genus of

\footnotetext{
${ }^{1}$ Pronunciation variant for Clerodendrum: $[\square \mathrm{kl} \square$ orə $\square \mathrm{d} \square$ ndrəm] (IPA); kleer-uh-den-druhm (English phonetic notation).
}

dichorhaviruses $\rightarrow$ the coffee ringspot disease-causing species of dichorhaviruses.

- Valid taxon name (fulfills ICVCN Article 3 Rule II3.8): yes, because name is compliant with ICVCN Article 3 Rules, in particular Rule IX-3.40; because it has been published [this article]; and because it is associated with descriptive material

- Accepted name (fulfills ICVCN Article 3 Rule II-3.8): no, because this name has yet to go through the ICTV approval process

- Use of the taxon:

- Style: capitalized, italicized, zero article

- Suggested pronunciation: ['kofi 'rinsppt dar,kprə 'varrəs ${ }^{2}$ ]; (IPA); kaw-fee ring-spot dahy-ko-ruhvahy-ruhs (English phonetic notation)

- Abbreviation: none

- Use of taxon vernaculars:

- n. sg.: coffee ringspot dichorhavirus. Suggested pronunciation: ['kofi 'rinsppt dar,kpro'varrəs] (IPA); kaw-fee ring-spot dahy-ko-ruh-vahy-ruhs (English phonetic notation)

- n. pl. coffee ringspot dichorhaviruses. Suggested pronunciation: ['kofi 'rinsppt daI,kprə'varrəsiz] (IPA); kaw-fee ring-spot dahy-ko-ruh -vahy-ruhsiz (English phonetic notation)

- adj.: coffee ringspot dichorhavirus/coffee ringspot dichorhaviral. Suggested pronunciation: ['kofi 'rinsppt daI,kprə'vairəs]/['kofi 'rinsppt daI,kprə 'vairəl] (IPA); kaw-fee ring-spot dahy-ko-ruhvahy-ruhs/kaw-fee ring-spot dahy-ko-ruh-vahyruhl (English phonetic notation)

- Style: lower case, not italicized, one word, zero article

- Abbreviation: none

- Species members are characterized by having the properties of dichorhaviruses; having an L gene polymerase motif nucleotide sequence different from the type virus of the type species of the genus Dichorhavirus (orchid fleck virus) by $>25 \%$; and infecting Coffea arabica

- Suggested type virus: coffee ringspot virus (CoRSV)

- Species members: coffee ringspot virus (CoRSV)

Description of Orchid fleck dichorhavirus sp. nov. Dietzgen et al. 2013 (tentative)

Etymology of Orchid fleck dichorhavirus: derived from orchid fleck disease (the disease caused by members of this

\footnotetext{
$\overline{2}$ Pronunciation variant: coffee ['kpfi] (IPA); kof-ee (English phonetic notation).
} 
species); and Dichorhavirus - the genus of dichorhaviruses $\rightarrow$ the orchid fleck disease-causing species of dichorhaviruses.

- Valid taxon name (fulfills ICVCN Article 3 Rule II3.8): yes, because name is compliant with ICVCN Article 3 Rules, in particular Rule IX-3.40; because it has been published [this article]; and because it is associated with descriptive material

- Accepted name (fulfills ICVCN Article 3 Rule II-3.8): no, because this name has yet to go through the ICTV approval process

- Use of the taxon:

- Style: capitalized, italicized, zero article

- Suggested pronunciation: ['orkıd flek dar,kprə 'varros ] (IPA); awr-kid flek dahy-ko-ruh-vahy-ruhs (English phonetic notation)

- Abbreviation: none

- Use of taxon vernaculars:

- n. sg.: orchid fleck dichorhavirus. Suggested pronunciation: ['orkıd flek dar, kprə'varrəs] (IPA); awrkid flek dahy-ko-ruh-vahy-ruhs (English phonetic notation)

- n. pl. orchid fleck dichorhaviruses. Suggested pronunciation: ['orkıd flek dar,kprə'varrəsiz] (IPA); awr-kid flek dahy-ko-ruh-vahy-ruhs-iz (English phonetic notation)

- adj.: orchid fleck dichorhavirus/orchid fleck dichorhaviral. Suggested pronunciation: ['orkıd flek daI, kpro'varrəs]/['orkıd flek daI kpro'varrəl] (IPA); awr-kid flek dahy-ko-ruh-vahy-ruhs/awr-kid flek dahy-ko-ruh-vahy-ruhl (English phonetic notation)

- Style: lower case, not italicized, one word, zero article

- Abbreviation: none

- Species members are characterized by having the properties of dichorhaviruses; having a full-length genomic sequence different from the type virus of the type species of the genus Dichorhavirus (orchid fleck virus) by $<10 \%$; and infecting orchid species

- Suggested type virus: orchid fleck virus (OFV)

- Species members: orchid fleck virus (OFV); citrus leprosis virus nuclear type (CiLV-N) 'Florida', a citrusinfecting strain of OFV

Description of Clerodendrum chlorotic spot virus vir. Kitajima et al. 2008 (as described in ref. [24])

Etymology of Clerodendrum chlorotic spot virus: derived from Clerodendrum chlorotic spot disease (the disease caused by this virus); and Lat. n. neut. sg. virus - poison, slime, venom.
- Use of the name:

- Style: first word capitalized (because proper noun), not italicized, all types of articles

- Suggested pronunciation: [,klerə'dendrəm klo'rotrk spot 'varrəs] (IPA); kler-uh-den-druhm klaw-rot-ik spot vahy-ruhs (English phonetic notation)

- Abbreviation: ClCSV

Description of coffee ringspot virus vir. Boari et al. 2004 (as described in ref. [4])

Etymology of coffee ringspot virus: derived from coffee ringspot disease (the disease caused by this virus); and Lat. n. neut. sg. virus - poison, slime, venom.

- Use of the name:

- Style: first word capitalized (because proper noun), not italicized, all types of articles

- Suggested pronunciation: ['kofi 'rinsppt 'varrəs] (IPA); kaw-fee ring-spot vahy-ruhs (English phonetic notation)

- Abbreviation: CoRSV

Description of orchid fleck virus vir. Doi et al. 1977 (as described in ref. [4])

Etymology of orchid fleck virus: derived from orchid fleck disease (the disease caused by this virus); and Lat. n. neut. sg. virus - poison, slime, venom.

- Use of the name:

- Style: first word capitalized (because proper noun), not italicized, all types of articles

- Suggested pronunciation: ['orkıd flek 'varrəs] (IPA); awr-kid flek vahy-ruhs (English phonetic notation)

- Abbreviation: OFV

Description of Viola ringspot virus vir. Gowanlock and Dietzgen 1995 (as described in ref. [18])

Etymology of Viola ringspot virus: derived from viola ringspot disease (the disease caused by this virus); and Lat. n. neut. sg. virus - poison, slime, venom.

- Use of the name:

- Style: first word capitalized (because proper noun), not italicized, all types of articles

- Suggested pronunciation: ['vaılə 'rinsppt'varrəs] (IPA); vahy-uh-luh ring-spot vahy-ruhs (English phonetic notation)

- Abbreviation: ViRSV 


\section{Proposal for nomenclature below the species level}

We propose to adapt the recently published nomenclature scheme for filovirus variants for dichorhavirus variants [35]. Accordingly, dichorhaviruses would be named $<$ virus name $><$ strain $>/<$ isolation host-suffix $>/$ $<$ country of sampling $>/<$ year of sampling $>/<$ genetic variant designation $>-<$ isolate designation $>$. Instructions on how to fill the individual fields can be found in ref. [35].

\section{Future prospects}

Functional and sequence similarities among members of non-segmented (-)ssRNA virus families (order Mononegavirales) and bisegmented viruses such as $\mathrm{OFV}$ and LBVaV suggest that they may share a common ancestor [48]. However, higher-level classification will require additional evolutionary data and/or 'fossil' sequences [16] to support or deny significant changes to the taxonomic system to accommodate such relationships. In this context it should be noted that rhabdovirus and varicosavirus $\mathrm{N}$ (CP)-like sequences have been found endogenized in several plant genomes [8]. If the virology community accepts the generation of a new genus with OFV as a member of its type species, then there are several options of future higher taxonomic placement within or outside of the family Rhabdoviridae and/or the order Mononegavirales that should be discussed for their merit. 1. The current definition of mononegaviruses would need to be revised to "predominantly nonsegmented" to allow inclusion of viruses with bipartite genomes in the Rhabdoviridae. 2 . Taxonomic placement in a new family outside of the Rhabdoviridae, but within the order Mononegavirales, would also require a more relaxed definition of what encompasses this order. 3. Classification could also be in a newly created order that may be named "(Poly)negavirales", including a new family, maybe including the genus Varicosavirus. The mono- and polynegaviruses could then come together in a new class "Negarnaviropsida". 4. Alternatively, a new order "Rhabavirales" could be created for all rhabdovirus-like viruses (rhabdoviruses + dichorhaviruses + varicosaviruses), and the four families Bornaviridae, Filoviridae, Nyamiviridae, and Paramyxoviridae could be elevated to order status; this would involve abandoning Mononegavirales and establishing a class for all those orders. Instead of new orders, suborders could also be established.

Note added in proof The recently sequenced citrus necrotic spot virus, strain Jal-1 from Mexico (GenBank accession numbers KF198064, KF198065) also appears to be a strain of ORF. The nucleotide sequences of its RNA 1 and RNA 2 are $90 \%$ identical to OFV and $96 \%$ identical to CiLV-N, respectively.

\section{References}

1. Adams MJ, Christian P, Ghabrial SA, Knowles NJ, Lavigne R (2011) Unassigned Viruses. In: King AMQ, Adams MJ, Carstens EB, Lefkowitz EJ (eds) Virus taxonomy-Ninth Report of the International Committee on Taxonomy of Viruses. Elsevier/ Academic Press, London, pp 1199-1207

2. Bastianel M, Novelli VM, Kitajima EW, Kubo KS, Bassanezi RB, Machado MA, Freitas-Astúa J (2010) Citrus leprosis. Centennial of an unusual mite-virus pathosystem. Plant Dis 94:284292

3. Blanchfield AL, Mackenzie AM, Gibbs A, Kondo H, Tamada T, Wilson CR (2001) Identification of Orchid fleck virus by reverse transcriptase-polymerase chain reaction and analysis of isolate relationships. J Phytopathol 149:713-718

4. Boari AJ, Freitas-Astua J, Ferreira PTO, Nader DG, Nogueira NL, Rossi ML, Kitajima EM (2004) Purification and serology of the coffee ringspot virus. Summa Phytopathol 30:453-458

5. Calisher CH, Carstens EB, Christian P, Mahy BWJ, Mayo MA, Shope RE (2000) Unassigned Viruses. In: van Regenmortel MHV, Fauquet CM, Bishop DHL, Carstens EB, Estes MK, Lemon SM, Maniloff J, Mayo MA, McGeoch DJ, Pringle CR, Wickner RB (eds) Virus taxonomy-Seventh Report of the International Committee on Taxonomy of Viruses. Academic Press, San Diego, pp 995-1008

6. Chagas CM, Kitajima EW, Rodrigues JC (2003) Coffee ringspot virus vectored by Brevipalpus phoenicis (Acari: Tenuipalpidae) in coffee. Exp Appl Acarol 30:203-213

7. Chang MU, Arai K, Doi Y, Yora K (1976) Morphology and intracellular appearance of orchid fleck virus. Jpn J Phytopathol 42:156-157

8. Chiba S, Kondo H, Tani A, Saisho D, Sakamoto W, Kanematsu S, Suzuki N (2011) Widespread endogenization of genome sequences of non-retroviral RNA viruses into plant genomes. PLoS Pathogens 7:e1002146

9. Childers CC, French JV, Rodrigues JC (2003) Brevipalpus californicus, B. obovatus, B. phoenicis, and B. lewisi (Acari: Tenuipalpidae): a review of their biology, feeding injury and economic importance. Exp Appl Acarol 30:5-28

10. Childers CC, Rodrigues JCV (2011) An overview of Brevipalpus mites (Acari: Tenuiplapidae) and the plant viruses they transmit. Zoosymposia 6:168-180

11. Dietzgen RG, Calisher CH, Kurath G, Kuzmin IV, Rodriguez LL, Stone DM, Tesh RB, Tordo N, Walker PJ, Wetzel T, Whitfield AE (2011) Family Rhabdoviridae. In: King AMQ, Adams MJ, Carstens EB, Lefkowitz EJ (eds) Virus taxonomy-Ninth Report of the International Committee on Taxonomy of Viruses. Elsevier/Academic Press, London, pp 686-714

12. Doi Y, Arai K, Yora K (1969) Distribution of bacilliform virus particles in Masaki mosaic disease and Cymbidium ringspot disease. Ann Phytopathol Soc Jpn 35:388

13. Doi Y, Chang MU, Yora K (1977) Orchid fleck virus. CMI/AAB Description of Plant Viruses No 183. http://wwwdpvwebnet/ dpv/showdpvphp?dpvno $=183$

14. Easton AJ, Pringle CR (2011) Order Mononegavirales. In: King AMQ, Adams MJ, Carstens EB, Lefkowitz EJ (eds) Virus taxonomy-Ninth Report of the International Committee on Taxonomy of Viruses. Elsevier/Academic Press, London, pp 653-657

15. Fenner F (1976) Classification and Nomenclature of VirusesSecond Report of the International Committee on Taxonomy of Viruses. Intervirology 7:1-115

16. Fort $\mathrm{P}$, Albertini A, Van-Hua A, Berthomieu A, Roche S, Delsuc F, Pasteur N, Capy P, Gaudin Y, Weill M (2012) Fossil rhabdoviral sequences integrated into arthropod genomes: ontogeny, evolution, and potential functionality. Mol Biol Evol 29:381-390 
17. Francki RIB, Fauquet CM, Knudson DL, Brown F (1991) Classification and nomenclature of viruses-Fifth Report of the International Committee on Taxonomy of Viruses. Archives of Virology Supplement, vol 2. Springer, Vienna

18. Gowanlock DH, Dietzgen RG (1995) Small rhabdovirus-like particles in violet (Viola spp.). Australasian Plant Pathol 24:215216

19. Jackson AO, Dietzgen RG, Goodin MM, Bragg JN, Deng M (2005) Biology of plant rhabdoviruses. Annu Rev Phytopathol 43:623-660

20. Kim SR, Yoon J-Y, Choi GS, Chang MU, Choi JK, Chung BN (2010) Molecular characterization and survey of the infection rate of Orchid fleck virus in commercial orchids. Plant Pathol $\mathbf{J}$ 26:130-138

21. King AMQ, Adams MJ, Carstens EB, Lefkowitz EJ (2011) The international code of virus classification and nomenclature. In: King AMQ, Adams MJ, Carstens EB, Lefkowitz EJ (eds) Virus taxonomy-Ninth Report of the International Committee on Taxonomy of Viruses. Elsevier/Academic Press, London, pp 1273-1277

22. Kitajima EW, Kondo H, Mackenzie A, Rezende JAM, Gioria R, Gibbs A, Tamada T (2001) Comparative cytopathology and immunocytochemistry of Japanese, Australian and Brazilian isolates of orchid fleck virus. J Gen Plant Pathol 67:231-237

23. Kitajima EW, Chagas CM, Rodrigues JC (2003) Brevipalpustransmitted plant virus and virus-like diseases: cytopathology and some recent cases. Exp Appl Acarol 30:135-160

24. Kitajima EW, Kubo KS, Oliveira Ferreira PDT, de Alcântara BK, Boari AJ, Gomes RT, Freitas-Astua J, Marques Rezende JA, de Morais GJ, Salaroli RB (2008) Chlorotic spots on Clerodendrum, a disease caused by a nuclear type of Brevipalpus (Acari:Tenuipalpidae) transmitted virus. Sci Agric 65:36-49

25. Kitajima EW, Rodrigues JCV, Freitas-Astua J (2010) An annotated list of ornamentals naturally found infected by Brevipalpus mite-transmitted viruses. Sci Agric 67:348-371

26. Kitajima EW, Chagas CM, Braghini MT, Fazuoli LC, LocaliFabris EC, Salaroli RB (2011) Natural infection of several Coffea species and hybrids and Psilanthus ebracteolatus by the Coffee ringspot virus (CoRSV). Sci Agric 64:503-507

27. Kitajima EW, Chagas CM, Harakava R, Calegario RF, FreitasAstúa J, Rodrigues JCV, Childers CC (2011) Citrus leposis in Florida, USA, appears to have been caused by the nuclear type of citrus leprosies virus (CiLV-N). Virus Rev Res 16:23-27

28. Kondo H, Maeda T, Tamada T (2003) Orchid fleck virus: Brevipalpus californicus mite transmission, biological properties and genome structure. Exp Appl Acarol 30:215-223

29. Kondo H, Maeda T, Shirako Y, Tamada T (2006) Orchid fleck virus is a rhabdovirus with an unusual bipartite genome. J Gen Virol 87:2413-2421

30. Kondo H, Maeda T, Tamada T (2009) Identification and characterization of structural proteins of orchid fleck virus. Arch Virol 154:37-45

31. Kondo H, Chiba S, Andika IB, Maruyama K, Tamada T, Suzuki $\mathrm{N}$ (2013) Orchid fleck virus structural proteins $\mathrm{N}$ and $\mathrm{P}$ form intranuclear viroplasm-like structures in the absence of viral infection. J Virol 87:7423-7434

32. Kondo H, Chiba S, Toyoda K, Suzuki N (2013) Evidence for negative-strand RNA virus infection in fungi. Virology 435:201209

33. Kubo KS, Stuart RM, Freitas-Astua J, Antonioli-Luizon R, Locali-Fabris EC, Coletta-Filho HD, Machado MA, Kitajima EW (2009) Evaluation of the genetic variability of orchid fleck virus by single-strand conformational polymorphism analysis and nucleotide sequencing of a fragment from the nucleocapsid gene. Arch Virol 154:1009-1014
34. Kubo KS, Novelli VM, Bastianel M, Locali-Fabris EC, Antonioli-Luizon R, Machado MA, Freitas-Astua J (2011) Detection of Brevipalpus-transmitted viruses in their mite vectors by RT-PCR. Exp Appl Acarol 54:33-39

35. Kuhn JH, Bao Y, Bavari S, Becker S, Bradfute S, Brister JR, Bukreyev AA, Chandran K, Davey RA, Dolnik O, Dye JM, Enterlein S, Hensley LE, Honko AN, Jahrling PB, Johnson KM, Kobinger G, Leroy EM, Lever MS, Muhlberger E, Netesov SV, Olinger GG, Palacios G, Patterson JL, Paweska JT, Pitt L, Radoshitzky SR, Saphire EO, Smither SJ, Swanepoel R, Towner JS, van der Groen G, Volchkov VE, Wahl-Jensen V, Warren TK, Weidmann M, Nichol ST (2013) Virus nomenclature below the species level: a standardized nomenclature for natural variants of viruses assigned to the family Filoviridae. Arch Virol 158:301311

36. Kuhn JH, Bekal S, Cai Y, Clawson AN, Domier LL, Herrel M, Jahrling PB, Kondo H, Lambert KN, Mihindukulasuriya KA, Nowotny N, Radoshitzky SR, Schneider U, Staeheli P, Suzuki N, Tesh RB, Wang D, Wang LF, Dietzgen RG (2013) Nyamiviridae: Proposal for a new family in the order Mononegavirales. Arch Virol. doi:10.107/s00705-013-1674-y

37. Locali-Fabris EC, Freitas-Astua J, Machado MA (2011) Genus Cilevirus. In: King AMQ, Adams MJ, Carstens EB, Lefkowitz EJ (eds) Virus taxonomy-Ninth Report of the International Committee on Taxonomy of Viruses. Elsevier/Avademic Press, London, pp 1139-1142

38. Matthews REF (1979) Classification and nomenclature of viruses - Third Report of the International Committee on Taxonomy of Viruses. Report prepared by the International Committee on Taxonomy of Viruses and published for the Virology Section of the International Association of Microbiological Societies (IAMS). Intervirology 12:129-296

39. Matthews REF (1982) Classification and nomenclature of viruses -Fourth Report of the International Committee on Taxonomy of Viruses. Report prepared by the International Committee on Taxonomy of Viruses and published for the Virology Division of the International Union of Microbiological Societies (IUMS). Intervirology 17:1-199

40. Mayo MA, Christian PD, Hillmann BI, Burunt AA, Desselberger U (2005) Unassigned Viruses. In: Fauquet CM, Mayo MA, Maniloff J, Desselberger U, Ball LA (eds) Virus taxonomyEighth Report of the International Committee on Taxonomy of Viruses. Academic Press, San Diego, pp 1131-1144

41. Peng DW, Zheng GH, Zheng ZZ, Tong QX, Ming YL (2012) Orchid fleck virus: an unclassified bipartite, negative-sense RNA plant virus. Arch Virol 158:313-323

42. Pringle CR, Alexander DJ, Billeter MA, Collins PL, Kingsbury DW, Lipkind MA, Nagai Y, Orvell C, Rima B, Rott R, ter Meulen V (1991) The order Mononegavirales. Arch Virol 117:137140

43. Pringle CR (1997) The Order Mononegavirales - current status. Arch Virol 142:2321-2326

44. Rodrigues JC, Kitajima EW, Childers CC, Chagas CM (2003) Citrus leprosis virus vectored by Brevipalpus phoenicis (Acari: Tenuipalpidae) on citrus in Brazil. Exp Appl Acarol 30:161-179

45. Roy A, Stone A, Otero-Colina G, Wei G, Choudhary N, Achor D, Shao J, Levy L, Nakhla MK, Hollingsworth CR, Hartung JS, Schneider WL, Brlansky RH (2013) Genome assembly of citrus leprosis virus nuclear type reveals a close association with orchid fleck virus. Genome Announc 1(4). doi:10.1128/genomeA. 00519-13

46. Sanchez A, Trappier SG, Mahy BW, Peters CJ, Nichol ST (1996) The virion glycoproteins of Ebola viruses are encoded in two reading frames and are expressed through transcriptional editing. Proc Nat Acad Sci USA 93:3602-3607 
47. Sasaya T, Ishikawa K, Koganezawa H (2002) The nucleotide sequence of RNA1 of Lettuce big-vein virus, genus Varicosavirus, reveals its relation to nonsegmented negative-strand RNA viruses. Virology 297:289-297

48. Tordo N, de Haan P, Goldbach R, Poch O (1992) Evolution of negative-stranded RNA genomes. Semin Virol 3:314-357

49. Tordo N, Benmansour A, Calisher C, Dietzgen RG, Fang R-X, Jackson AO, Kurath G, Nadin-Davis S, Tesh RB, Walker PJ (2005) Family Rhabdoviridae. In: Fauquet CM, Mayo MA, Maniloff J, Desselberger U, Ball LA (eds) Virus taxonomyEighth Report of the International Committee on Taxonomy of Viruses. Academic Press, San Diego, pp 623-644

50. Van Regenmortel MH, Burke DS, Calisher CH, Dietzgen RG, Fauquet CM, Ghabrial SA, Jahrling PB, Johnson KM, Holbrook MR, Horzinek MC, Keil GM, Kuhn JH, Mahy BW, Martelli GP, Pringle C, Rybicki EP, Skern T, Tesh RB, Wahl-Jensen V, Walker PJ, Weaver SC (2010) A proposal to change existing virus species names to non-Latinized binomials. Arch Virol 155:1909-1919

51. Vetten HJ, Haenni AL (2006) Taxon-specific suffixes for vernacular names. Arch Virol 151:1249-1250

52. Volchkov VE, Becker S, Volchkova VA, Ternovoj VA, Kotov AN, Netesov SV, Klenk HD (1995) GP mRNA of Ebola virus is edited by the Ebola virus polymerase and by $\mathrm{T} 7$ and vaccinia virus polymerases. Virology 214:421-430
53. Walker PJ, Benmansour A, Calisher CH, Dietzgen RG, Fang RX, Jackson AO, Kurath G, Leong JC, Nadin-Davis S, Tesh RB, Tordo N (2000) Family Rhabdoviridae. In: van Regenmortel MHV, Fauquet CM, Bishop DHL, Carstens EB, Estes MK, Lemon SM, Maniloff J, Mayo MA, McGeoch DJ, Pringle CR, Wickner RB (eds) Virus taxonomy-Seventh Report of the International Committee on Taxonomy of Viruses. Academic Press, San Diego, pp 563-583

54. Walsh JA, Verbeek M (2011) Genus Varicosavirus. In: King AMQ, Adams MJ, Carstens EB, Lefkowitz EJ (eds) Virus taxonomy-Ninth Report of the International Committee on Taxonomy of Viruses. Elsevier/Academic Press, London, pp 777-781

55. Wildy P (1971) Classification and nomenclature of viruses-First Report of the International Committee on Nomenclature of Viruses. S. Karger, Basel

56. Wunner WH, Calisher CH, Dietzgen RG, Jackson AO, Kitajima EW, Lafon M, Leong JC, Nichol ST, Peters D, Smith JS, Walker PJ (1995) The Rhabdoviridae. In: Murphy FA, Fauquet CM, Bishop DHL, Ghabrial SA, Jarvis AW, Martelli GP, Mayo MA, Summers MD (eds) Virus taxonomy-Sixth Report of the International Committee on Taxonomy of Viruses Archives of Virology Supplement, vol 10. Springer, Vienna, pp 275-288 